\title{
The Emergence of an Entitlement Framework for Stored Tissue - Elements and Implications of an Escalating Conflict in Sweden
}

\author{
Klaus Hoeyer
}

In 1999, a biotech company was established in Västerbotten County, in Sweden, and given what was termed 'all commercial rights' to a major research biobank containing blood samples of the majority of the adult population. It was predicted that the company would place the otherwise rather marginalised community at the centre of international life-science research. International investments failed to appear, however. During the spring of 2002, internal disagreements concerning dispositional rights in the biobank resulted in court appeals, critical newspaper articles and, more informally, mutual threats among parties with different interests in the biobank material. In this article, it is argued that scrutiny of this conflict provides a chance to understand the emergence of delineated entitlements in material contained in Swedish biobanks.

Keywords: property relations, social entitlements, genetic databases

"It's the worst kind of soap opera... It's like pure fiction. Nobody will ever believe what's happening!"

Employee at the Medical Biobank, spring of 2003

This article relates the story of an escalating conflict over a biobank in Sweden. At a first glance, the conflict resembles a typical property controversy. However, the contested object is human tissue, which introduces a moral discourse of personhood that moderates conventional commercial property claims. To analyse the implications of the conflict the concept of social entitlements is suggested, in the sense of specified rights recognised by other parties. The concept of social entitlement is broader than property rights and includes non-commercial entitlements, such as the right to informed consent or the right to figure as trustee, besides more conven- 
tional commercial entitlements as intellectual property rights. It is the creation of such distinctions between various types of entitlement, which is the focus of this paper.

The conflict concerns Medical Biobank, and the start-up biotech company UmanGenomics, in the town of Umeå in northern Sweden. In 1999, UmanGenomics gained what was termed "exclusive commercial rights" to a collection of blood samples from the majority of the adult population in Västerbotten County. By arrangement, blood samples have been collected from subjects (aged 40,50 and 60 years) taking part in a public preventative healthcare project. Samples have been taken during medical examinations and stored in what is today termed Medical Biobank. The preventative healthcare project began in one municipality in 1985. In 1986, some researchers assisting in the implementation of the project began collecting spare samples of blood. In 1987, such collection was officially approved with the stipulation that the principal investigator (PI) would find the necessary external funding. ${ }^{1}$ In 1991, the collection was extended to the whole county together with a general expansion of the healthcare project. Over the years, 78,000 blood samples have been collected from 68,000 individuals.

The project continued until the mid1990s without public debate or major institutional conflict. Within academia, however, it was sometimes questioned whether the accumulation of such huge amounts of samples was worthwhile. Some local academics viewed the biobank as a waste of money and the PI was occasionally referred to in derogatory terms. He nevertheless succeeded in get- ting grants from different organisations - the EU, among others - and the county council authorized the staff conducting medical examinations to collect $20 \mathrm{ml}$. of blood from each participant. The matter of who owned the collected blood was not an issue of debate or discussion. The blood was regarded simply as an available resource and researchers who wished to make use of it applied to a panel of experts convened by the PI to oversee such usage.

Two interrelated developments disturbed the apparent harmony. First, advancements in gene technology, and the belief that biotechnology was on the brink of a revolution, made large-scale blood-collection interesting to a great number of researchers wanting access to this reservoir of DNA from a whole population. Second, the ideology of the Free Market (Carrier, 1997) had altered the structures of government funding for research and placed new demands upon universities to cooperate with private companies (Etzkowitz \& Webster, 1998; Etzkowitz et al., 1998). Public authorities were to facilitate profitable and cost-effective public/private interaction (cf. Webster \& Packer, 1996); and the idea of providing a company with "exclusive commercial rights" was seen as an effective way of meeting this responsibility. It gradually became clear, however, that several institutions and individuals thought of themselves as disposing over the stored blood and an intense struggle was thereby set in motion.

The preliminary sketch of the resulting conflict provided in this paper demonstrates how property relations as a particular type of social entitlement might be emerging in the field of biobanks: not as a consequence of rational 
calculating actors attempting to maximise their own profit, but rather as an unanticipated effect of other types of struggle. The conflict nevertheless seems to outline a future framework for social entitlements in biobanks, and we might even begin to see the contours of this framework. I will argue that four sources of entitlement seem to be established with four different forms of adjoining rights:Trusteeship (organisational rights, right to sign contracts); Authorship (intellectual property rights, right to make money); Funding (fund-control rights, veto rights); Genetic originatorship (moral rights, right to informed consent).

This paper will explicate their emergence, content, and possible implications. While some of these entitlements reflect broader national or international trends, the emerging framework cannot be reduced to a consequence of existing regulations or international developments. The actual definition of delineated entitlements is pending appropriation by local social networks. The conflict is a local history infusing claims with meaning, and it serves to test the viability of what are still just potential entitlements.

It is a feature of the conflict that the contested biobank does not contain updated medical records, though it does hold questionnaire data from the time of collection. Though vanguard research has been conducted using this information and public disease registries, updated phenotypic information is central for much of the genetic research facilitated by the biobank. Such information, however, has to be procured through other means: for example, through collaboration with practicing physicians. The conflict therefore revolves around a partly artificial object: blood, detached from the information giving it much of its commercial and scientific value. This paper seeks to identify the ways in which such specific configurations of the conflict seem to enable particular distinctions between entitlements not previously differentiated, thus creating a future framework for entitlements in Swedish biobanks.

\section{Methods and Analytical Concepts}

This paper is based on ethnographic fieldwork conducted intermittently (for approximately 12 months between June 2000 and August 2003) primarily in and around Umeå, as well as in two locations in Lapland. The conflict evolved during fieldwork, but was not its intended focus. I had set out to explore the social implications of the UmanGenomics ethics policy, using a wide range of different methods (interviews, participant observation, informal conversations, lunch and dinner arrangements, participation in conferences, receptions, meetings and analysis of documents ranging from official laws and statutes to letters and protocols) with diverse subjects and settings (blood donors, nurses collecting blood, the biobank, the company, funding agencies). Throughout fieldwork, I had good relations with employees at the biobank and in the company. As the conflict evolved, many informants became eager to talk about it and gradually the conflict became an object of study in its own right, causing me to approach other parties suggested by key informants (for other briefer descriptions of the conflict see Laage-Hellman, 2003; Lövtrup, 2003; Rose, 2003).

Commercialisation of genetic data- 
bases is comparable to the birth of other commodities: a process known to be surrounded by intense moral conflict (Pálsson, 2002), as originally discussed by John Locke with relation to private land ownership (see Witte \& Have, 1997). Commercialisation requires that different forms of entitlement be sorted out in order to create what is known as ownership, or property rights. Swedish biobanks constitute a type of resource in which the entitlements of different groups have not been made legally clear. There are no delineated social entitlements agreed upon by the parties involved in Swedish biobanking. The conflict in Umeå is helping to establish such clarity. We should not expect, however, that the resulting framework will ever be permanently fixed. We are simply witnessing the formation of an important starting point for future conflicts.

Analysis of the conflict indicates that the opposed parties are increasingly questioning what ownership means and implies. Clearly, the conflict revolves around more than property rights. For example, several informants have claimed that tissue cannot be owned for moral reasons, which resonates with legal practices exempting the human body from traditional property frameworks. Also, the right to informed consent is inappropriate to the idiom of property, particularly when evoked with reference to the moral status of tissue. In order to avoid ownership or property as key analytical terms, the broader concept of social entitlement is used to denote specified (not necessarily commercial) rights recognised by other parties.

The element of recognition is central and has political as well as moral aspects: Recognition must be obtained from others (constituting a source of power); and it entails having one's personal sense of agency respected (constituting a moral issue) (cf. Taylor, 1994). The moral aspect of recognition includes respect for professional expertise and can be strived for independently of property rights or other types of entitlements, though it can be expected to influence these entitlements. The concept of power employed here reflects the later writings of Michel Foucault (1986; 1992; 1994), where the interrelatedness of ethics, knowledge and power was analysed. When operating successfully, well-defined social entitlements (such as property rights) can be perceived as a culturally specific form of power, which serves to install unequal vectors of distribution upheld and respected by both dominant and dominated parties: a structuring principle affecting the restrictions we impose on our conduct. It is a form of power, however, which is not yet adequately established in the field of stored human tissue in Sweden.

In an essay on property relations, Marilyn Strathern (1999) has observed that no vocabulary is unbiased. No matter how terms are used, they will reveal something and hide something else. Hence, social entitlement is a concept with limitations of its own. For example, economist Lars-Peter Østerdahl (p.c.) has pointed out that the concept of entitlement reflects a liberal economist tradition in which entitlements reside with individuals and reflect individual capabilities. In contrast, this paper focuses on the social processes in which not only individuals, but groups, organisations and other entities, as well, become recognised as having entitlements. It was Cris Hann's (1998) discussion of social enti- 
tlements that made me realise how this concept made it possible to ask the broad analytical question, "How are social entitlements established?", detached from an explicit consideration of property rights. It seemed a new pattern was emerging from three empirical questions with which the material had been approached: 1) what do different actors seek to attain?; 2) what do they do to attain that?; and 3) how does that affect their own or other people's rights in the biobank material? Ownership per se did not appear to be what the involved actors were seeking to attain. Rather, property claims were being used as leverage in the actors' quest for recognition. This phenomenon does influence the way in which social entitlements in stored tissue are changing, or at least how they are becoming explicated and entrenched, because the introduction of a proprietary idiom facilitates particular distinctions and specifications. The proprietary idiom is used as people aim for other types of social entitlements.

To support this inference I recount selected elements of the escalating events in Umeå. Though the events are delivered partly as a narrative, I do not wish to suggest a thick internal logic to the story, but I do try to impose some analytical order by sorting them according to three time periods. In the first phase, we see the emergence of two opposing groups. The second phase focuses on how the trust between these two groups was eroded. This background helps us to understand the reasons for the courses of actions that were taken, which in the third phase, lead to the establishment of delineated entitlements. These entitlements are subsequently elaborated upon in relation to the laws predominantly applied during the last phase to support specific sources of entitlement.

\section{Phase 1 (1997- September, 2000): Establishing Groups of Opposition}

When I first arrived in Umeå, everybody was very enthusiastic about this new biotech adventure. The seeds of conflict, however, were already there. The PI, who had been head of the biobank since its inception, had hoped to test a commercial concept: the biobank was to have a marketing branch where pharmaceutical companies could pay to access the material. Accrued profits would be the property of Medical Biobank and would be used for research. Personal profit was not a motive. Rather, the objective was enhanced utilisation of the biobank resource, and thus recognition of its scientific worth. Both university management and the county council became involved in planning and the decision was made to invite someone with corporate experience to give advice. The person who was hired, a former research director in a major pharmaceutical company, was brought in from Stockholm and made chairman of the board in Medical Biobank. He instituted a change in the commercial concept from a marketing branch under the authority of the biobank to an independent start-up biotech company fully detached from the biobank. He has explained to me that he was subsequently invited by the university to leave the biobank and become manager of the company that became UmanGenomics. The university's holding company would own the majority of company shares and the key to the company's survival would be 'exclusive com- 
mercial rights'. Thus, the university and council took custody of the biobank and assigned their own company the right to exploit it. The biobank's principal investigator, however, was not convinced of the plan.

In trying to ensure a positive introduction and avoid media trouble, the company's newly-appointed manager had begun work on an ethics policy even prior to the signing of contracts with the county council and the university. For this purpose, he contacted a respected professor of paediatrics, who was chair of several ethics committees, including the Medical Research Council's Board for Ethics in Research. With the Professor's assistance, the company developed an ethical model that was called the "Uman-Model", and launched the company. In 1999, both Nature and Science referred to UmanGenomics as an ethical exemplar (Abott, 1999; Nilsson \& Rose, 1999). The Uman-Model was never written down, but it consisted of some descriptions of ethical safeguards at three levels: the individual level, where each donor would give informed consent; the regional level, where UmanGenomics would apply to the research ethics committee for approval of each research project; and the national level, where the university and the county council would own a majority of shares in UmanGenomics to ensure public oversight and community benefit-sharing. According to Swedish law, the county is not allowed to make a profit. This issue was resolved, however, by providing the county with the right to buy shares at any time.

As part of the new arrangements, the organisation of the biobank was transferred to the authority of the county council. The transfer was regarded by biobank staff as a mixed blessing. On the one hand, they hoped this would finally lead to secure funding; on the other hand, the formerly free researchers were now more regulated, or even "reduced to a service agency", as one employee put it. Importantly, with regards to both the transfer and the setup of a new biotech company, the biobank employees felt they had been inadequately involved in decision-making. Other people were equally surprised that they had not been asked for an opinion, including members of the Regional Research Ethics Committee and the Chief Medical Officer managing the local university hospital, who had taken over as chair of the board at the biobank. The Research Ethics Committee was invited to give comments only a couple of hours before the contract proposal was to be presented to the county politicians, in the beginning of 2000 . Several ethics committeemembers were dissatisfied that the committee was being used for ethical promotion of the company though they had not been consulted earlier for ethical advice. The biobank's principal investigator also began to prove an unusually difficult employee at this time. In 1999, when the terms of cooperation between the biobank and the company were negotiated, the PI had written an e-mail to the university management expressing genuine dissatisfaction with the contract proposal and deploring his lack of involvement with its drafting. ${ }^{2}$ Around these events, therefore, emerged two opposing groups: those actively involved, and those feeling merely informed, and usually too late (see Figure 1). 
Figure 1. Two opposing groups engaged in the conflict

\begin{tabular}{l|l} 
Those who were positively involved & $\begin{array}{l}\text { Those feeling unfairly excluded } \\
\text { from decision-making }\end{array}$ \\
\hline - the university management & $\begin{array}{l}\text { - the staff of Medical Biobank } \\
\text { and their research partners }\end{array}$ \\
- the county council & $\begin{array}{l}\text { - the hospital manager } \\
\text { - selected academics }\end{array}$ \\
- the company & $\begin{array}{l}\text { - the Research Ethics Committee } \\
\text { related supporters }\end{array}$
\end{tabular}

\section{Phase 2 (September, 2000-April, 2002): Erosion of Trust}

The company nevertheless got started. The sense of proximity to something big and important for the region, perhaps even for the nation and humanity, probably helped keep the conflict out of the public domain. Start-up capital had been secured from an agency working with technology transfer from universities to private companies, researchers and support staff was employed, and new high-profile offices established. With the burst of the biotech investment bubble, however, investors and customers failed to appear. The company and the technology transfer agency both pointed to the agreement between UmanGenomics and the county council and university as the source of the problem. Public majority ownership of the company might look good in ethical models, but it did not facilitate commercial confidence. In addition, the contract's stipulation mandating that the company feed back all research results to the biobank was perceived as incompatible with the requirements of customers and investors. It took two years, however, before a proposal for a new contract between the company and the authorities was presented. During this time, a number of incidents undermined any sense of trust between the parties of the conflict.

Two incidents adding to the hostility in this period were of particular importance. The first related to the custody of a diabetes registry suggested by UmanGenomics. The biobank group had, for some years, tried to establish registrymanagement facilities in conjunction with the biobank, but when they immediately tried to fit the diabetes registry into these plans, UmanGenomics regarded this as an attempt to co-opt the company's idea. Thus, the PI was seen by the company as an intellectual thief, while the company and university management were seen by the biobank as unfairly seizing the biobank's research plans. Instead, UmanGenomics undertook collaboration with another respected researcher at the university, who accepted the offer of getting funding for the registry and took the task of facilitating its construction. His choice, in a sense, demarcated lines of disagreement in the academy, taking the conflict beyond the directly involved parties and slowly dividing the medical faculty as a 
whole into two opposing groups, as had occurred with the academy in Iceland (Rose, 2001).

The second incident occurred during the autumn of 2001, when UmanGenomics issued new shares and offered them to selected members of the university and the county council, and to the corporate elite in Umeå. The biobank group saw this move as a particularly obvious example of an immoral use of power and economic influence. This precipitated a rash of other objections and disagreements. The staff, in turn, with its constant opposition to practically every corporate initiative, was probably seen by the company and authorities again as unprepared for the realities of business life.

At this point, the initial manager from Stockholm left the company, and a Scottish researcher took over the post as director. Concomitantly, the company withdrew from the centre of conflict, leaving their case to be fought by the university and county. In April 2002, the contractual relationship between the company and the authorities, which was blamed for problems with failing investments, was changed, and the intense and toxic internal conflict became public.

\section{Phase 3 (April, 2002 - ): Carving out Entitlements}

The biobank's principal investigator objected to the new proposal and sent an email to each member of the board of the county council prior to the vote. This might have influenced some of them; at least, the first proposal was rejected. The company was under great pressure to get the proposal through and to ensure new capital. A slightly altered proposal was quickly presented for another vote. This time, it passed. Immediately after the new contract was passed in the county council, it was submitted to the local appeals court for legality-testing. The staff of Medical Biobank, though not the PI personally, submitted several complaints. Local newspapers covered the conflict extensively. Along with articles came letters in the correspondence column and in the newspaper's online discussion forum. Several of the letters were anonymous and clearly aligned with one or the other side of the conflict. These letters often made moral claims and since then there has been an outburst of public accusations in the idiom of ethics.

The invocation of ethics indicates a testing of entitlements in a field inadequately governed by law, and is worth a comment. Besides newspapers, the conflicting parties have found several avenues for moral vindication. The university arranged a conference on the ethical aspects of biobanking, where the principal explained that the conflict was essentially a moral conflict, and that the action taken by the university board was an ethical solution. ${ }^{3}$ Six weeks later, the biobank sent a letter accusing the university and the county of breaking numerous laws. The letter also declared that it is the duty of every citizen to place ethics over all other concerns and even to break the law if it conflicts with justice. ${ }^{4}$ The letter spurred the Research Ethics Committee to write a commentary on the ways in which organisational changes of Medical Biobank might conflict with the Helsinki Declaration.

There are obvious reasons for referring to ethics. Biotechnology seems to be embedded in an ethicised discursive 
environment (Hoeyer, 2002). Ethics can be expected to awake sympathy and thus stimulate support, which is essential for people struggling for recognition. In this third phase it is not only ethics, however, but also the application of law which contributes to the demarcation of delineated entitlements. The combination of ethics and law shows the high level of contingency of the present boundaries. Reference to ethics is a resource when interpreting laws that have potential relevance for the entitlements in Swedish biobanks. The analytical understanding of law that informs this analysis basically sees it as an extension of elements in public morality and, therefore, as embodying a certain amount of legitimacy. A law's legitimacy emerges through the cases where the existing sense of entitlement resonates with the law. Law has to prove itself (Moore, 1978). As a written document, however, law is open to new interpretations and can be used for purposes discordant with the legitimising norms (cf. Foucault, 1986).

Each source of entitlement is established through contestation. One party might not initially find it relevant when a particular law is drawn into conflict by the other party. However, the way in which both parties subsequently seek to demonstrate the applicability of this law to their own entitlements to the biobank strengthens the legitimacy of this specific source of entitlement. At some point, we can expect reference to law to be a sufficient argument in most conflicts, because the matter of interpretation will become increasingly routine. Entitlements, however, will never be totally fixed, because any source of entitlement can potentially be challenged. Only in this very unsettled field is the contingency plain and observable.

The formation of delineated entitlements, illustrated by the following events, relates to two areas of law: administrative law and property law (cf. Fleising \& Smart, 1993), which will be discussed in turn. Administrative law particularly informs the entitlements of trusteeship and what I above termed genetic originatorship (i.e., the entitlements of donors). Property law, in turn, informs the formation of entitlements particularly associated with authorship and funding, while also having implications for the role of originatorship, as discussed in the final section of this paper.

\section{Administrative Law and the Entitlements of Trusteeship and Genetic Originatorship}

At the heart of the legality trial at the appeals court was the right of the county council to sign contracts with the company. The court found for the defendant, ${ }^{5}$ though one case has been accepted for retrial and the university and county thus seem to have had their entitlement to sign contracts confirmed by the case. Parallel with the local conflict, a law was passed to regulate biobanks in the Swedish healthcare service (Socialdepartementet, 2002). This law introduces registration of trusteeship of public biobanks and stipulates that, in general, trustees must be legal persons, not natural persons. This prevents principal investigators from registering material in their own name, again supporting the right of county and university, now as trustees, to sign contracts concerning biobanks. Several researchers in Umeå, some of them members of the REC, have reacted strongly to this, seeing it as an 
infringement of their natural dispositional rights in material they have collected personally.

The biobank researchers have also written several letters of complaint concerning the biobank law in general. In particular, they oppose what they see as a conflation into trusteeship of three different sources of entitlement, namely 'ownership' (that they think should belong to the donor), dispositional rights (belonging to the principal investigators), and day-to-day administrative responsibility (that they would happily transfer to the county council). Thus, they have opposed the notion of trusteeship as the right of an organisation to sign contracts conflicting with the dispositional interests of researchers. Simultaneously, however, they have been trying to register the biobank with national authorities in order to protect their own 'dispositional rights'. Needless to say, the county council has filed an application of registration of trusteeship, as well. Both applications were originally dismissed, however, and the two parties asked to settle their conflict prior to registration. ${ }^{6}$ As this proved difficult, the national authorities later ruled that trusteeship would rest with the county ${ }^{7}$, thus demarcating the contours of a trusteeship specifically in terms of the right to sign contracts.

The county and the university attempted at once to achieve the position of trustee and to execute the organisational power it can be expected to involve. An effect of the court trial was that the limits of diplomacy between these two groups were clearly reached and the conflict subsequently intensified. The university commissioned extra auditing of the biobank unit, which presumably revealed faults, ${ }^{8}$ but the biobank staff challenged the report and no one was ever fired. Another unsuccessful attempt to fire the PI resulted in his unwilling transfer back to the university. Having held the county post as biobank manager for one three-year term, he was replaced. The PI had been offered another term, with an increase in salary, but he refused because the contract included a condition that the county be given control of the biobank. Though he no longer officially holds the post, he has continued to call himself biobank manager and he has not given up the claim to entitlements that now seem to rest with the position of trustee. In the Spring of 2003, the county opened up another front in the war. It argued that, as the PI was no longer an administrative manager employed by the county council (he was merely a university researcher with no obligations toward the county's healthcare service) the research group was no longer entitled to occupy the offices at the university hospital. A transfer of offices was proposed, but has still not been executed, and might never be.

The university and county in turn commissioned a report reviewing the organisational structure of the biobank. ${ }^{9}$ The report was never published, but a new agreement was signed on 19 March 2003 , between the university and the county, revising this structure. The revision stated that the same person could not simultaneously be administrative manager, member of the board of the biobank, and member of the REC. There was no mention of the expert groups originally established by the PI. A mandate as extensive as the one previously issued to the PI would presumably not be possible in the future. This demar- 
cated and sustained the entitlements of trustees and clarified that they involved the right to delegate distinct mandates to specified office holders. The biobank staff, as well as the REC, immediately objected to this rearrangement, and it too was submitted for legality testing at the appeals court.

As the second court case demonstrated, the demarcation of trustee entitlements does not go uncontested. By this point, the biobank group had furthermore already formulated a counter suggestion: a revised structure for the management of the biobank involving all parties perceived by the biobank as being legitimately interested (in reality, these parties were comprised of the persons previously placed in the expert groups that had been shut down with organisational rearrangement). This newly-proposed structure was called the Joint Steering Committee (JSC) and just like the board appointed by the university and the county council, it was to dispose of biobank materials. With the establishment of JSC, there were two separate management teams and two boards - and considerable public confusion. Even more important for this analysis is the fact that in opting for trusteeship through JSC (and the applications for registration with the national authorities), the biobank researchers contributed to bringing trusteeship, as a source of entitlement, into being.

If the county council has been using registration and its right to appoint administrative managers and dispose of hospital offices to gain control of the biobank, the university management has been struggling to be recognised as employer. The university attempts to portray the conflict as an issue between employer and employee which is exemplified in the following response, by the principal, to a letter from the biobank group:

"Parallel with your right to express pri-
vately any opinion whatsoever con-
cerning the adequacy of the decisions
of the university board, it is not toler-
able that you, as employees at the uni-
versity, act in a way that might provide
an erroneous image of the resolution
of the university board and your own
position within the respective authori-
ties. (...) In the event of further corre-
spondence concerning these issues,
you must beware of your way of expres-
sion..." Lines of command, however, can only functions as such when recognised by both superiors and inferiors. The principal has had to realise that the power exercised in organisations is not static or easily defined. When a leader is not adequately recognised and respected, he is liable to experience frustration tantamount to that experienced by employees, like the PI, when they find that their work and competence are not recognised as they would have wished.

During this period, all documents have been scrutinised and no battle has been too small to fight. Many letters have had massive numbers of attachments and occasionally, both parties have circulated copies of the same attachments as documentation for separate claims. Swedish public law dictates extensive access to all public records and old letters have been procured from the archives and commented upon with new letters. It is as if every document is perceived as essential evidence of one or the other party being right or wrong. The meaning, even the potential meaning, of every sign and signal has become an 
object of strife. This is a war of signification - because signs are recognition. As a consequence, there can be no innocent description. The conflict thus impinges even on my work, making every sentence into an act of balancing interests.

With the Biobank Act, private ownership in human tissue, or at least commercial exploitation of it, was banned (Socialdepartementet, 2002). It is now stated that human tissue cannot be owned, though research results emanating from it may be. The biobank staff has accordingly accused the county and university of illegal commodification of human tissue. As a consequence, the university and the county have had to reduce the amount of money they were supposed to receive from UmanGenomics in exchange for the 'exclusive commercial rights', making the biobank an expense, not a possible source of income. The entitlements of trustees thus seem to crystallise as a custodianship with organisational power incompatible with commercial rights.

This separation of research information from human substance follows an international trend, but it is in no way uncontroversial (Rose, 2001), and it has implications for the entitlements of donors, as well. Based on British material, Tutton (2004) has termed the policy processes in this area 'boundary work,' where it is the installation of new boundaries that is at stake. The emerging boundary between human tissue and the research it facilitates demarcates also the emerging boundary between the social entitlements of donor on the one hand and researcher or research institution on the other (Hoeyer, 2002). The Biobank Act also ingrains the use of informed consent in relation to tissue-based research in Sweden and, consequently, establishes genetic originatorship as a source of entitlement (cf. Strathern, 1999; Novas \& Rose, 2000). The donor becomes entitled to give informed consent. This again reflects an international trend (Tutton, 2004) given local meaning (Hoeyer, 2004). It is the way law is used in the conflict, however, which reveals the practical implications of this demand, as discussed below.

\section{Property Law and the Entitlements of Funding and Authorship}

The organisation of the Joint Steering Committee described above is the PI's attempt to re-establish legitimacy in the control of the biobank, in the face of what he perceives to be illegitimate confiscation. ${ }^{11}$ The effort to gather all parties with legitimate interests, of course, is itself an exercise in the morality of social entitlement: whom does the PI recognise? ${ }^{12}$

The invited parties included university management and county representatives, the biobank research group claiming to have developed the concept of a large-scale biobank, and representatives of the main funding agencies. Whereas the first group corresponds to the notion of trusteeship suggested by administrative law, and is approved by the university and the county, the latter two find support primarily in intellectual property law and constitute the PI's addition. I will first discuss funding as a source of entitlement, and then follow with observations on researchers' entitlements.

Obviously, the university and county have dismissed the legitimacy of the Joint Steering Committee, as such. Still, 
in their correspondence with funding agencies, they seem to acknowledge that funding might provide entitlement to approve or veto future agreements regarding the biobank. Even more significantly, they have argued for their own entitlements through documentation of their direct and indirect funding of the biobank (e.g. through the payment of the nurses collecting blood). In this way, funding is becoming established as a source of entitlement.

The limits to this entitlement, however, are also being demonstrated. As trusteeship may not involve commercial rights, and as the county wishes to be recognised both as trustee and funding agency, the motivation to acknowledge funding as a source of entitlement to commercial rights is limited. Besides, in the carving out of two groups of opposition, the county and the university have come to be aligned with UmanGenomics and they are therefore inclined to protect the company's presumed 'exclusive commercial rights' granted in contracts signed by both county and university. Also, if they were to moderate or abandon this concept, they could erode their own mandate as trustees. Therefore, the county and the university back the granting of entitlements to funding agencies while defining these entitlements narrowly in terms of administrative rights and duties compatible with their emerging understanding of trusteeship. Tissue (as a substance) should be administered properly and not converted into a profitable commodity.

The PI has also apparently invited funding agencies to the JSC, primarily in acknowledgement of their entitlement to veto presumably unlawful exploita- tion, but not for them to share potential profit. This interpretation is supported by property law, which recognises funding as a source of a particular type of intellectual property rights (IPR): namely, database protection. To be acknowledged, funding should be substantial and one might expect that more than $50 \%$ of the resource should be utilised in order for contingent rights to be legally violated, though these criteria are yet to be determined by case law. However, as Sweden exempts university teachers from the framework of intellectual 'background' rights of host institutions and funding agencies, which applies in many countries (Webster \& Packer, 1996) and ensures university researchers possession of their own patentable inventions, the rights of funding in such a case are limited to protect against "unauthorised extraction and/or re-utilisation of the whole or a substantial part of the compilation" (Hellstadius et al., 2003: 218). The point is that reference to property law helps to establish funding as a source of entitlement by explicating gradually more defined, though weak, rights: mainly a form of veto right to exploitation, which substantially compromises the intentions of the project originally funded.

Concerning researchers' contributions, lawyers have recently suggested that a biobank structure could represent an original intellectual contribution and thus merit copyright (Hellstadius et al., 2003). The work of collecting samples is not, however, a source of entitlement in itself. The biobank structure includes the system of ordering samples according to a coding system. Importantly, the PI has control of the code key. If he did not intend to transfer the key to the custody 
of the county before, he certainly has less reason to do so after realising that this coding system, from a civil law perspective, might be considered his personal property. As property law does not recognise property in bodily tissue, the 'boundary work' described above is confirmed, and entitlements of researchers relegated to original intellectual contributions, which can and should be commercially exploited. We thus see a further demarcation of entitlements. Researchers are entitled according to the originality of their intellectual contribution. I term this authorship in acknowledgement of its origin in intellectual property law.

There is, however, a contradictory character to the claims of property rights. The biobank staff allows public exposure of the biobank structure, which they should avoid if they wanted it to function as a for-profit institution (Hellstadius et al., 2003). Indeed, the PI and his supporters serve as advisers to the Norwegian government and to a steering group laying out new Swedish national guidelines where they give away what they are supposed to make revenue from. This, they argue, is because they finally feel recognised by somebody. Their property claim is not stimulated by a wish for property - it is used as leverage of recognition. It is not recognition alone, of course, that is at stake. Without being recognised as having the dispositional rights to the biobank, there are fewer opportunities with funding agencies. Their jobs and careers are therefore also at stake.

In the course of these debates, UmanGenomics has failed to acquire further funding. During the Spring of 2003, the research staff was laid off and in-house research projects brought to a halt. The company still exists and presumably retains its exclusive commercial rights. Should anybody else produce valuable research on the biobank material, it is still UmanGenomics that owns the intellectual rights to its exploitation.

\section{An Entitlement Framework for Biobanks in Sweden?}

Having identified trusteeship, originatorship, funding and authorship as four sources of entitlement, we can discuss the type of innovation they might represent, as well as its possible implications. Had the biobank had access to electronic patient records, as did its more famous Icelandic counterpart, which was run by deCODE (Merz et al., 2003), the legal framework invoked would have been different and GPs may have taken a more active stance in opting for entitlements to decide who should share the information they convey (cf. Pálsson \& Hardardóttir, 2002). Had the conflict involved active patient organisations, they could also very well have featured (cf. Smaglik, 2000). In the following, I try to explicate further the type of innovation entitlements represent and elaborate on the practical implications we might already observe.

The entitlements of funding agencies in academic research are relatively weak and ill-defined in Sweden, due to the socalled teacher's exemption. The conflict, however, with its reference to property law, has contributed to a clarification of what type of influence funding agencies should expect to have. The entitlements of donors provide a more significant innovation worth elaborating in some detail. Though informed consent is novel 
in relation to biobank research, the addition made by conflict is not originatorship as a source of entitlement as such (see Strathern, 1999), but a particular interpretation and use of the resulting law.

The conflict has implied a consistent articulation of the obligations toward donors. The informed consent forms used in the project have been scrutinised and interpreted by both parties and, not surprisingly, both sides have concluded that the consent form has presented them as recipients of the sample. Subsequently, both parties have begun developing their own consent forms. UmanGenomics developed one form, which explained to donors that they were entitled to withdraw their consent, and mentioned that they would have no commercial rights in research results. Another form was developed by the biobank and called a 'withdrawal form'. When some donors who, after the media debate, approached Medical Biobank and wanted their samples destroyed, they were asked to complete this form, which provided, as an alternative to destruction, that their samples be designated for academic research or clinical purposes only. Ironically, the PI who initially pushed for commercialisation, found himself increasingly in alliance with people opposing commercial involvement in medical research. In addition, some nurses, reluctant to collect samples for commercial use, at first refused to ask patients for blood, and have since reverted to the use of an old consent form developed before the launch of UmanGenomics. These nurses have arranged with the biobank that blood collected by them should be treated and used according to the former system. As the county officials, to whom the nurses report, have not been involved in this process, it has remained a covert practice; a tacit opposition performed by some nurses and disdained by others. A united occupational group might have been in the position to affect the outcome of the conflict, but to do so they should probably have aligned themselves with the only rhetoric that nobody dares to oppose any longer: the donors' entitlement to make decisions concerning the use of their own blood.

The intensified interest in informed consent emerges as it becomes clear that the consent form might be used to clarify who should dispose of the contested tissue. This produces a surprising new understanding of informed consent among policy makers. Though introduced in public law through the rhetoric of respect for the individual, the conflict has entrenched the view that, from a civil law perspective, informed consent is a contract defining dispositional rights. The moral relation established between donors and their samples subsequently not only entitles donors to information, but also obliges them to stay informed and distribute commercial rights they can no longer enjoy themselves.

An equally intriguing and unexpected innovation relates to the interplay of authorship and trusteeship. The legitimacy of IPR rests partly on widely shared notions of the relationship between people and their ideas. If ideas can be conceived of as stemming from original and autonomous creation, they can be owned (Foucault, 1991; see discussion in Teilmann, 2000; 2001). This again reflects particular notions of human agency as stemming from autonomous individuals (Mauss, 1985). In line with this cognitive framework, Sweden has previ- 
ously primarily allocated IPR directly to university researchers as their private property. In business life, however, this does not work. Commercial research institutions need to control the knowledge capital generated by their employees. Therefore, the establishment of UmanGenomics necessitated the introduction of commercial entitlements, other than direct authorship.

In the capacity of trustees, or in the attempt to establish this capacity, the university and the county first removed the entitlement to sign contracts concerning commercial exploitation of biobanks from the original intellectual contribution (authorship) of the research group. This was justified partly by the need to secure the interests of the community as a whole, rather than those of individual researchers. The university and the county then used this entitlement to sign a contract with their own company. The community could expect to benefit directly from commercial gain, since community institutions owned UmanGenomics. The Biobank Act then clarified that trustees should not commodify tissue in their custody. Accusations from the biobank made it clear that charging a profit-related fee for access to the biobank might be considered commodification. As UmanGenomics then pressured the county and the university to release them from public majority ownership, trustees lost the entitlement to profit. The county and the university thus had to give up both their shares and the entitlement to receive a precentage of the profit from UmanGenomics for maintenance of the biobank. Original intellectual contributions were the legitimising source of IPR and were subsequently replaced with a com- munity share model. Recent developments, however, have separated IPR from the community, as well. The entitlement to profit now rests with shareholders.

This arrangement has implications for the incentive structure. When companies, funding agencies or universities are entitled, through law, to IPR in the research projects they host (so-called background rights), such entitlements are generally supposed to create a structure of incentives (Webster \& Packer, 1996). With UmanGenomics, however, those who execute or facilitate research no longer find themselves entitled to the IRP stemming from it. The company no longer initiates its own research, but basically exists to retain the 'exclusive commercial rights' to research carried out by others (presumably academic researchers), whom they expect to use Medical Biobank. Hence, a deficient incentive structure has been established. In addition, more generally, this entitlement framework might prove to be a problem. If researchers are not entitled to use the material they collect and are not entitled to their original intellectual contributions, they will have limited future incentives for constructing new biobanks and for exploiting those biobanks where commercial entitlements have been allocated to private companies.

Though marketed as 'exclusive commercial rights', it was never really clear what these rights implied. It was probably more like a first right of refusal and, in my understanding, this was how UmanGenomics would have approached the matter. They would not have liked to run into a battle with researchers upon whom they might later have to depend for follow-up on the research they were 
trying to market: access, for instance, to the essential updated phenotypic information not contained in Medical Biobank. The question remains, however, who benefits from the insistence on involving private companies in the exploitation of human biobanks and from the clear demarcation between commercial entitlements and trusteeship. The community where authorities have obligated themselves to provide a company with pro bono service can hardly be regarded as a beneficiary. Nor, indeed, can the donors be seen as such. Even the shareholders of UmanGenomics would probably have been better off with a more modest business model, building on achieved research results (authorship) rather than first rights of refusal to as yet imaginary research.

\section{Conclusion}

While a purely person-oriented interpretation of the conflict has been avoided in this analysis, it has been suggested to stay aware of the role of recognition, which does indeed work at the level of interpersonal relations. Awareness of the role of recognition, rather than exclusive focus on property relations, might provide a more complete understanding of the use of ethics in the conflict. It is tempting to regard references to ethics merely as a tool in the establishment of power. Indeed, it has been shown above how arguments of ethics are used in the establishment of delineated entitlements, including property relations. When scrutinising the action taken by the parties of this conflict, however, the line of reasoning could just as well be turned around. To some degree, tools of power (e.g. rights of the employer/prop- erty law) are used to fulfil people's sense of fairness, to achieve respect, and to protect people's sense of agency; that is, moral, rather than political or financial, goals.

It is important to note that the emerging sources of entitlement are not what the actors involved in the conflict opted for, nor would these sources necessarily accommodate their future interests particularly well. Though people clearly aim to defend their interests, the outcome is not necessarily consistent with their intentions. Rather, the entitlement framework seems to emerge out of more complex forms of interplay in moral and legal dispute. The law has an agency of its own, as it were, and so does moral reasoning. Once particular sources of entitlement are launched publicly as moral arguments, they seem to engage actors in areas of dispute that had not been considered relevant before. International trends in promoting public/private interaction, political changes, and moral changes leading to the establishment of genetic originatorship, as well as the international legal framework for IPR, provide opportunities for action, but these trends do not determine the course of the action. The resulting social entitlements represent a pattern in the flow of actions, a pattern which will be the starting point for future conflicts rather than a permanent structure.

The entitlement framework had to be disentangled sooner or later, because increasing commercial involvement with healthcare databases necessitates legal support of entitlements. The clarification of entitlements has taken a form different from other intellectual property disputes, in that it concerns an object for which the usual definitions used 
in commercial relations are not entirely appropriate. The bodily component necessitates particular forms of reasoning, and is embedded in an ethicised environment. The framework developed through this conflict will have implications for other biobanks. I have already met researchers who are considering how it will influence their current projects and future initiatives. Still, we might ask if there could have been a different outcome and whether the situation is about to change. I would certainly argue that the interpretation of trusteeship and the use of informed consent could have been settled differently. Whether these settlements will take the form suggested in the argument above depends upon how people answer the following questions: Are we happy with the use of informed consent as a contract? Are we happy with the role determined for trustees? Do we think that a better incentive structure could be established? For what purposes do we want to establish incentives?

In this paper it has been argued that the conflict contributes to the establishment of a more clearly defined framework for social entitlements in stored human biological material. This framework facilitates distinction between different sources of entitlement and different adjoining rights. Analytical attention has been given to the social processes of establishing entitlements, rather than to the personal experiences of the conflict because in the course of the actions taken, new vectors of inequality and control emerge that deserve critical attention.

\section{Acknowledgement}

I would like to thank the people engaged in the conflict for relating their stories to me and for keeping me informed far beyond what any external commentator could expect. Some informants have also commented very usefully on a draft of the paper, though I cannot name them here for reasons of confidentiality. Richard Tutton, Lene Koch, Sniff Nexø, Andrew Webster, Åsa Hellstadius, and Niels Lynöe have contributed immensely by reading and discussing earlier versions, and the participants at a seminar at the Centre for Family Research, University of Cambridge, and the Vital Politics Conference, London School of Economics, where earlier versions of the paper were presented, likewise gave very useful comments.

\section{Notes}

1 Memo by Birgitta Strandman, Västerbotten County Council 17/11-1987, and letter to Karl-Axel Ängkvist from Karl-Eric Karlsson, Västerbotten County Council 13/6-1995.

2 E-mail to Jan-Erik Ögren from Göran Hallmans, 28/12-1999. He also claimed copyright (upphavsmannarätt) to a commercial concept - a claim that was later revived in an amended version, as discussed below.

3 Medicinsk-odontologiska fakultetens rådgivande kommité for etikfrågor (Advisory Committee on ethical issues of the Medical-Odontological Faculty), University of Umeå, 17/2-2003. "Biobanker-Etik och praksis".

4 Letter to the Management of Umeå University and Management of Västerbotten County Council, from Torgny Stigbrand and Göran Hallmans, 7/4-2003.

5 Appeals Court (Länsrätten) in Västerbotten County, sentence in case 668-02, 4/10-2002. 
6 Letter to Västerbotten County Council, Umeå University and Medical Biobank from Ingmar Hammer, Department of Health (Hälso- och sjukvårdavdelningen), National Board of Health and Welfare, 19/ 3-2003, VCC 50-10642/02 (when a code follows a documentary reference, the first letters identify the registry, Västerbotten County Council [VCC]/Medical Biobank $[\mathrm{MB}] /$ Umeå University [UU], and the number the registry code).

7 Letter to Västerbotten County Council, Umeå University and Medical Biobank from Per-Anders Sunesson, Department of Health, National Board of Health and Welfare 10/ 10-2003, UU 503-948 03.

8 Gunnar Nyström, Internal Revision Department, Umeå University 6/11-2002, Granskning av Enheten för Naringsforskning och Medicnska Blodbanken vid Umeå Universitet.

9 Västerbotten County Council and Umeå University. Direktiv för översyn av avtal rörande Medicinska Biobanken vid Norrlands Universitetssjukhus och Umeå universitet. 26/6-2002. UU 192-1948-02. A similar need has been pointed out by the biobank, as well, with reference to an audit commissioned as part of the biobank quality assurance. See Göran Hallmans to Västerbotten County Council and Umeå University 3/10-2002. Kvalitetsrevision vid Medicinska biobanken. MB 67/2002.

10 Letter to Torgny Stigbrand and Göran Hallmans from Inge-Bert Täljedal 19/82003, MB 74/2003, my translation.

11 See for example, Letter to Department of Health, National Board of Health and Welfare, from Medical Biobank, 18/7-2003.

12 The meeting took place on February 13, 2003. The invitation and minutes can be obtained from Medical Biobank.

\section{References}

Abbott, A.

1999 "Sweden Sets Ethical Standards for Use of Genetic ‘Biobanks'.” Nature 400: 3.
Carrier, J.G. (ed.)

1997 Meanings of the Market. The Free Market in Western Culture. Oxford: Berg.

Etzkowitz, H. \& Webster, A.

1998 "Entrepreneurial Science: The Second Academic Revolution." Pp. 21-46 in H. Etzkowitz, A. Webster, \& P. Healey (eds.), Capitalizing Knowledge. New Intersections of Industry and Academia. New York: State University of New York Press.

Etzkowitz, H., Webster, A., \& Healey, P.

1998 "Introduction." Pp. 1-20 in H. Etzkowitz, A. Webster, \& P. Healey (eds.), Capitalizing Knowledge. New Intersections of Industry and Academia. New York: State University of New York Press.

Fleising, U. \& Smart, A.

1993 "The Development of Property Rights in Biotechnology." Culture, Medicine and Psychiatry 17 (1): 43-57.

Foucault, M.

1986 The Care of the Self. London: Penguin Books.

1991 “What Is an Author?" Pp. 102-120 in P. Rabinow, ed., The Foucault Reader. An Introduction to Foucault's Thought. London: Penguin Books.

1992 The Use of Pleasure. London: Penguin Books.

1994 Viljen tilViden. Seksualitetens Historie 1 [TheWill to Knowledge: History of SexuHann, C.M. ality 1]. Copenhagen: Det Lille Forlag.

1998 "Introduction: The Embeddedness of Property." Pp. 1-47 in C. M. Hann (ed.), Property Relations. Renewing the Anthropological Tradition. Cambridge: Cambridge University Press.

Hellstadius, Å., Wolk, S., \& Wessman, R.

2003 "Intellectual Property and Biobanks." Pp. 207-225 in M. G. Hansson \& M. Levin (eds.), Biobanks as Resources for Health. Uppsala: Research Programme Ethics in Biomedicine.

Hoeyer, K.

2002 "Conflicting Notions of Personhood in Genetic Research.” Anthropology Today, 18 (5): 9-13.

2004 "Bioetik i praktiken. Etiken som regleringsmetod." in S. Lundin, (ed.), En ny kropp. Essäer om mediciniska visioner och personlig val. Nordic Academic Press, Lund. 
Laage-Hellman, J.

2003 "Clinical Genomics Companies and Biobanks - The Use of Biosamples and Commercial Research on the Genetics of Common Diseases.” Pp. 51-90 in M. G. Hansson \& M. Levin (eds.), Biobanks as Resources for Health. Uppsala: Research Programme Ethics in Biomedicine.

Lövtrup, M.

2003 "Drömmen om Bioklippet Slutade i Affärsmässig Anemi [The Dream of a Biotech Adventure Ended in Financial Anaemia]". Dagens Medicin, 10/11.

Mauss, $\mathrm{M}$.

1985 "A Category of the Human Mind: The Notion of Person; the Notion of Self," Pp. 1-25 in M. Carrithers, S. Collins, \& S. Lukes (eds.), The Category of the Person. Anthropology, Philosophy, History. Cambridge: Cambridge University Press.

Merz, J.F., McGee, G.E., \& Sankar, P.

2003 "'Iceland Inc.'?: On the Ethics of Commercial Population Genomics.” Social Science \& Medicine 58 (6): 1201-1209.

Moore, S. F.

1978 Law as Process. An Anthropological Approach, 2. ed., 2000 edn. Oxford: James Currey.

Nilsson, A. \& Rose, J.

1999 "Sweden Takes Steps to Protect Tissue Banks." Science 286: 894.

Novas,C. \& Rose,N.

2000 "Genetic risk and the birth of the somatic individual." Economy and Society 29: 485-513.

Pálsson, G.

2002 "Medical Databases. The Icelandic Case.” Pp. 22-41 in S. Lundin \& L. Åkesson (eds.), Gene Technology and Economy. Lund: Nordic Academic Press.

Pálsson, G. \& Hardardóttir, K.

2002 "For Whom the Cell Tolls." Current Anthropology 43 (2): 271-301.

Rose, $\mathrm{H}$.

2001 The Commodification of Bioinformation: The Icelandic Health Sector Database. London: The WellcomeTrust.

2003 "An Ethical Dilemma. The Rise and Fall of UmanGenomics - The Model Biotech Company?" Nature 425: 123-124.
Smaglik, P.

2000 "Tissue Donors Use Their Influence in Deal Over Gene Patent Terms." Nature 407: 821.

Socialdepartementet

2002 Lag om Biobanker i Hälso- och Sjukvården m.m. [Law on Biobanks in Public Healthcare etc.]. 2002:297.

Strathern, M.

1999 Property, Substance and Effect. Anthropological Essays on Persons and Things. London: The Athlone Press.

Taylor, C.

1994 “The Politics of Recognition.” Pp. 75106 in D. T. Goldberg (ed.), Multiculturalism. A Critical Reader. Oxford: Blackwell.

Teilmann, S.

2000 "Flaubert's Crime: Trying Free Indirect Discourse." Literary Research/Recherche Littéraire 17 (33): 74-87.

2001 "Propritærer og Plagiarister. En Indføring i Nyere Litteraturtyveri [Property Holders and Plagiarists. An Introduction to Recent Literary Theft].” Kritik 150: 4-11.

Tutton, R.

2004 "Person, Property and Gift: Exploring Languages of Tissue Donation to Biomedical Research" in R. Tutton \& O. Corrigan (eds.), Genetic Databases: Socio-ethical Issues in the Collection and Use of DNA. London: Routledge.

Webster, A. \& Packer, K.

1996 "Patens and Technology Transfer in Public Sector Research: The Tension Between Policy and Practice." Pp. 4364 in J.Kirkland (ed.), Barriers to International Technology Transfer. London: Kluwer Academic Publishers.

Witte, J. \& Have, H. T.

1997 "Ownership of Genetic Material and Information." Social Science and Medicine 45 (1): 51-60.
Klaus Hoeyer
Department of Health Services Research University of Copenhagen, Denmark
k.hoeyer@pubhealth.ku.dk 